\title{
ТЕОРЕТИЧНІ ТА МЕТОДИЧНІ ЗАСАДИ РОЗВИТКУ ІННОВАЦІЙНОЇ КУЛЬТУРИ МАЙБУТНЬОГО КЕРІВНИКА ЗАКЛАДУ ЗАГАЛЬНОЇ СЕРЕДНЬОӦ ОСВІТИ У ПРОЦЕСІ МАГІСТЕРСЬКОЇ ПІДГОТОВКИ
}

у статті схарактеризовано основні теоретичні та методичні заходи розвитку інноваційної культури майбутнього керівника закладу загальної середньої освіти. Визначається зміст основних понять, принципів і підходів до формування культури керівника закладу освіти, обгрунтовується необхідність иілеспрямованої підготовки майбутнього керівника установи до інноваційної діяльності в управлінні. Готовність педагога до інновачійної діяльності визначається важливою професійною якістю. Розглянуто інноваційну культуру керівника закладу загальної середньої освіти як складову його загальної культури. Відзначено, що інноваційна культура керівника закладу загальної середньої освіти пов'язана з його інноваційним і творчим мисленням, є основою його самореалізації.

Ключові слова: інноваційна культура, розвиток інновачійної культури, керівник закладу загальної середньої освіти, магістратура, магістерська підготовка.

Постановка проблеми. «Не викликає сумніву, що на сьогодні серед численних реформ освітнього сектору, необхідним $\epsilon$ забезпечити суспільство висококваліфікованими професійними кадрами, серед яких значне місце посідають керівники закладів загальної середньої освіти. Тому що школа виступає одним із першим інститутів на шляху розвитку і становлення особистості» (Сидоренко, 2014, с. 149).

Входження України до європейського простору провокує необхідність забезпечення формування потенціалу нації, здатної творчо й ефективно вирішувати завдання, швидко адаптуватися до нових реалій. Даний процес стає неможливим без розвитку інноваційного потенціалу особистості, ключове місце в якому посідає інноваційна культура як стратегічний ресурс нового століття.

Підтвердженням цього є Указ Президента України № 344/2013 від 25.06.2013 року «Про Національну стратегію розвитку освіти в Україні на період до 2021 року», у якому зазначено, що інноваційний сталий розвиток суспільства, економіки неможливо здійснювати без послідовного запровадження передових науково-педагогічних технологій, раціональних і ефективних підходів до організації наукової та інноваційної діяльності у сфері освіти, тобто підтримки інноваційної діяльності педагогічних і керівних кадрів країни (Мурована, 2012).

Сьогодення характеризується зміною змісту, форм, методів та засобів навчання, виховання й управління, зумовленою інноваційними процесами та реформуванням у системі освіти, орієнтацією на виробництво й ринкову 
економіку, появою значної конкуренції. Упровадження таких кардинальних інновацій в освіті потребує високого рівня сформованості інноваційної культури керівника закладу загальної середньої освіти (33СО).

Аналіз актуальних досліджень. Сучасні дослідники, розглядаючи теоретичні та методичні заходи розвитку інноваційної культури майбутнього керівника закладу загальної середньої освіти в процесі магістерської підготовки, виділяють низку проблем та аспектів даної теми: з погляду сучасних умов, інноваційних підходів, стратегії управління інноваціями, інноваційних технологій, інноваційного менеджменту тощо. Проблеми управління закладами освіти досліджені в роботах Ю. Атаманчука, В. Григораша, Л. Даниленко, Г. Єльнікової, С. Калашнікової, Л. Калініної, Л. Карамушки, О. Мармази, Є. Павлютенкова, В. Пікельної, Є. Хрикова та ін.

Підготовка керівників закладів загальної середньої освіти до інноваційної діяльності розкрита в працях Н. Василенка, Н. Меркулової. Особливості управлінсько-педагогічної підготовки керівників закладів освіти в сучасних умовах розглядають М. Елькін, А. Коробченко і М.Головкова. Сучасні підходи до визначення інноваційної культури керівника та стратегії управління інноваціями представлено в роботах О. Любіна, А. Ніколаєва, Л. Водачек та ін. Психолого-педагогічні аспекти формування інноваційної культури керівника представлено в роботах В.Петрова, Н. Кузьміної, В. Кременя, В. Загвязинського та ін. Значний інтерес становлять дослідження інноваційних технологій моделей освітнього процесу в закладах вищої освіти, які розкриті в наукових працях такими вченими, як: М. Кларіна, О. Мєщанінова, А. Наливайка, Т. Рожнової та інші. Проблеми інноваційного менеджменту освіти досліджуються в наукових працях В. Андрущенка, В. Беха, Л. Ващенко, Л. Даниленко, В. Жукової, Л. Калініної, В. Маслова, Н. Погрібної, А. Крижанівського, Є. Павлютенкова, В. Паламарчука та інших.

Дослідження проблем історичного розвитку галузі управління в освіті та становлення професії керівників закладів освіти знаходимо в наукових працях: С. Майбороди (управління навчальними закладами України (20-ті 30-ті роки XX ст.). О. Мармази (становлення та розвиток управління в галузі освіти), В. Пікельної (зародження науки управління освітою та їі розвиток), Л. Васильченко, І. Гришиної (історіографія проблеми формування професійної компетентності керівників шкіл), В. Береки (історико-педагогічний аналіз проблеми фахової підготовки магістрів з менеджменту освіти).

Вважаємо, що в науковій літературі достатньо ґрунтовно досліджено саме окремі аспекти обраної нами теми. Проте саме відсутність системного підходу до їі висвітлення спонукає до подальших наукових розвідок у царині інноваційної культури майбутнього керівника закладу загальної середньої освіти.

Аналіз досвіду управлінської діяльності й досліджень проблем управління закладами освіти дозволили зробити висновок про те, що у 
процесі магістерської підготовки майбутніх керівників закладів загальної середньої освіти не повною мірою висвітлено аспект розвитку їх інноваційної культури як детермінуючого фактору підвищення ефективності функціонування закладу освіти в сучасних умовах.

Мета статті полягає у визначені теоретичних та методичних засад розвитку інноваційної культури майбутнього керівника закладу загальної середньої освіти у процесі магістерської підготовки.

Методи дослідження. У ході дослідження використано комплекс взаємопов'язаних теоретичних методів: аналіз, синтез, порівняння, зіставлення різних поглядів на проблему дослідження, узагальнення.

Виклад основного матеріалу. Перехід України на інноваційний етап розвитку вимагає зміни поглядів на ресурси системи підготовки керівників закладів загальної середньої освіти, потребуючи впровадження інноваційних технологій навчання та створення умов для ефективного формування інноваційної культури керівника.

Пошук ефективних організаційних форм управління новаціями, створення механізму інтеграції та координації діяльності в процесі розробки й упровадження нововведень вимагають підвищення уваги до інноваційної культури як цілісної системи вироблених у $33 \mathrm{CO}$ i притаманних ії колективу моделей поведінки, що впливають на стиль та спосіб життєдіяльності закладу.

«Проблема підготовки майбутніх керівників закладів освіти до інноваційного управління - це порівняно нова наукова проблема, що має комплексний міждисциплінарний характер. ІІї вирішення вимагає аналізу основних напрямів підготовки майбутніх керівників закладів освіти до інноваційного управління в системі вищої, післядипломної та додаткової професійної освіти» (Сас, 2014, с. 8).

«В умовах швидкої зміни навколишнього середовища, підвищеної ризикованості, невизначеності висуваються нові вимоги до управління закладами освіти, зокрема - до підготовки діючих і майбутніх їх керівників» (Сас, 2014, с. 10-11).

Модернізація в сфері освіти вимагає якісних змін у мисленні та організаційній поведінці керівника закладу освіти. Сучасним менеджерам освіти доводиться вирішувати складні управлінські питання щодо забезпечення якості освіти, формування конкурентоспроможності закладу на ринку освітніх послуг. Якість управління в освіті відображається в успішності закладу і значною мірою залежить від управлінської компетентності керівників освіти, від їх готовності до інноваційних змін, без яких неможливий будь-який розвиток. Відтак, здобуття навичок інноваційного управління, формування інноваційного мислення та інноваційної культури керівника $33 С 0$ набуває особливої актуальності. 
Н. Сас наводить основні завдання інноваційного управління, серед яких: аналіз закономірностей розвитку інноваційних процесів, тенденцій організаційно-економічних нововведень; розробка й реалізація адаптивної оновленої відповідно до умов сучасності корпоративної стратегії; освоєння сучасних управлінських інноваційних технологій (економічних, психологічних, діагностичних, інформаційних); реалізація заходів для розвитку персоналу; створення нових організаційних форм управління; застосування управління на основі цільових програм і проектів; просування інноваційного процесу, прогнозування можливих перешкод, визначення шляхів їх подолання; моніторинг використання ресурсів, виділених під виконання функцій інноваційного управління (Сас, 2014).

Досить широкий спектр питань та завдань, із якими стикаються сучасні менеджери освіти, спонукає до більш ґрунтовного дослідження методологічних засад та принципів дослідження інноваційної культури управління в освіті.

Методологічні основи розвитку інноваційної культури майбутніх керівників 33СО розкриваються через теоретичні положення, що представлені науковими підходами й принципами розвитку. Поділяємо думку більшості науковців щодо основоположних принципів розвитку професійної культури керівників 33СО, а саме: традиційні (науковості, наступності й послідовності розвитку, безперервності, динамічності, систематичності) і специфічні (гуманізації, ціннісно-смислової спрямованості, культуровідповідності, єдності загальної і професійної культури, проектування особистісної траєкторії розвитку, співтворчості, індивідуалізації самоосвіти й саморозвитку, інноваційного розвитку, комплексності, ситуаційного розвитку професійної культури). Оскільки формування інноваційної культури керівника $33 С 0$ провокує сприйняття нових інноваційних ідей, готовність та здатність до підтримки й реалізації інновацій у всіх сферах діяльності закладу, розвиток інноваційної культури вимагає використання таких наукових підходів, як: культурологічний, аксіологічний, акмеологічний, синергетичний (Мурована, 2012).

Далі наведемо принципи, на які належить спиратися під час дослідження інноваційної культури управлінця в освіті, а саме:

- науковості - використання досягнень наукових дисциплін, що мають своїм об'єктом людину, соціум, організацію, працю;

- системності, що передбачає сприйняття в єдності об'єктів дослідження, факторів, що на них впливають та інших супроводжувальних чинників формування культури;

- гуманізму, який ґрунтується на визнанні цінності людини та духовності як основної мети розвитку особистості;

- професіоналізму, що передбачає наявність у дослідника адекватної освіти, наукового світогляду та прагнення істини (Мармаза, 2016). 
Терміном «інноваційність» науковці позначають певні аспекти діяльності організації - адміністрування, маркетинг, фінанси, дизайн, керівництво кадрами, послуги. Для забезпечення інноваційності в діяльності організації потрібно переглядати як стратегію та раціональність роботи, так і швидкість упровадження накопиченого досвіду. у науковому обігу такі аспекти забезпечення одночасних змін здобули загального визначення «тотальна інноваційність». Науковець Ю. Блудова вважає готовність педагога до інноваційної діяльності важливою професійною якістю. Дослідниця визнає можливість відсутності інноваційного підходу вчителя до освітнього процесу, що в результаті призведе до зниження ступеня педагогічної підготовленості випускника педагогічного 3ВО (Нордстрем, 2011).

Готовність педагога до інноваційної діяльності $\epsilon$ важливою професійною якістю, і відзначаючи відсутність інноваційної підготовки майбутнього вчителя, у процесі якої в нього міг би сформуватися інноваційний підхід до освітнього процесу, робить висновок, що в цілому це знижує ступінь педагогічної підготовленості випускника педагогічного вишу.

Інноваційна діяльність керівника ЗСО регламентується відповідними законодавчими актами та теоретико-методологічними розробками вчених.

Згідно з Законом України «Про пріоритетні напрями інноваційної діяльності в Україні», одним із провідних напрямів інноватики є формування інноваційної культури суспільства в цілому та особистості зокрема.

«Інновація - це будь-яка цілеспрямована зміна технології управління, що орієнтується на заміну їі елементів для прискорення, пом'якшення або поліпшення виконання поставлених завдань» (Клімова, 2012).

Інноваційна управлінська діяльність керівника закладу загальної середньої освіти визначається Н. Погребною як сукупність специфічних управлінських принципів, функцій та технологій, у результаті застосування яких забезпечується постійний розвиток закладу освіти та підвищується його конкурентоспроможність (Погрібна, 2007).

Професійну культуру О. Мармаза розглядає як систему соціальних якостей, що безпосередньо забезпечує рівень трудової діяльності. За енциклопедичним словником, професійна культура характеризує «рівень та якість професійної підготовки» (Мармаза, 2016). За Законом України «Про пріоритетні напрямки інноваційної діяльності в Україні» (ст. 2), інноваційна культура - складова інноваційного потенціалу, що характеризує рівень освітньої, загальнокультурної і соціально-психологічної підготовки особистості та суспільства в цілому до сприйняття і творчого втілення в життя ідеї розвитку економіки країни на інноваційних засадах (Закон України «Про пріоритетні напрями інноваційної діяльності в Україні» від 16 січня 2003 року N 433-IV). Цілком логічно, що поняття інноваційної культури особистості виходить із поняття культури взагалі як сукупності матеріальних і духовних цінностей. При цьому інноваційна культура педагогічних працівників 
визначається як система професійних засобів особистісного розвитку, що забезпечує інноваційний спосіб педагогічної діяльності, провідним компонентом якої є цінності інноваційної педагогічної діяльності (Мурована, 2012, с. 55). Ми розглядаємо інноваційну культуру керівника закладу загальної середньої освіти як складову його загальної культури, що $\epsilon$ інтегративною характеристикою фахівця і включає в себе особистий інноваційний потенціал, сформований у ході реалізації соціально-освітніх нововведень, стиль управлінської діяльності та готовність керівника впроваджувати нові елементи у зміст, методику, організацію й управління освітнім процесом. Інноваційна культура керівника забезпечує готовність до генерування та імплементації нових ідей, здатність підтримувати й реалізовувати інноваційні технології навчання в освітньому процесі, спроможність упровадження сучасних управлінських механізмів у сучасній освіті.

Інноваційна культура керівника 33 зо значною мірою пов'язана 3 його інноваційним і творчим мисленням i, з одного боку, є основою його реалізації та розвитку, а з іншого - сама зазнає трансформації через вплив творчого мислення, яке відображає динамічні зміни в соціальноекономічній, інституційній та організаційній сферах держави.

Виходячи з того, що інноваційна культура керівника 33 со трактується науковцями як цілеспрямована зміна технології управління, що забезпечує готовність до генерування та імплементації нововведень, зазначимо, що підготовка майбутнього керівника до управлінської діяльності потребує ретельного аналізу досліджень щодо основних складових інноваційної культури особистості.

Більшість сучасних науковців схиляються до класичного компонентного складу структури культури особистості: когнітивний (знання); діяльнісний (уміння); мотиваційний (основні мотиви носія культури до ефективної діяльності); особистісний (особистісні якості). Проте аналіз досліджень щодо складників інноваційної культури особистості дозволяє виокремити такі: потенціал і творчі здібності особистості (знання, уміння, інтелект, творча активність) та предметний результат діяльності (техніка, технологія, інформація, твори мистецтва, норми права, моралі тощо). У виокремленні складових інноваційної культури керівника закладу ЗСО ми орієнтуємося на структуру інноваційної діяльності вчителя, розроблену О. Козловою, компонентний склад інноваційної культури керівника ЗНЗ Н. Мурованої: світоглядний; когнітивний; мотиваційний; креативний; суб'єктнодіяльнісний (Kozlova, 2014).

Готовність керівника закладу освіти до запровадження інноваційної діяльності - це забезпечення якісної освітньої послуги, що відповідає сучасним вимогам до підготовки майбутніх фахівців. Він $є$ професіоналом своєї справи, який творчо підходить до вирішення певної задачі чи досягнення конкретного результату. Модернізація освітньої галузі, звісно, 
неможлива без інноваційних менеджерів, які відповідають наміченій державою стратегії розвитку освітньої галузі.

Керівник закладу освіти має відчувати постійну потребу прогресивних змін, а відтак передбачати перспективи роботи закладу освіти. Формування інноваційної культури керівника 33 СО варто розглядати не як одномоментний, швидкоплинний процес, а зважати на те, що як будь-яке соціологічно-психологічне явище, він проходить певні рівні й наділений певними рисами. Низький (стихійний) рівень характеризується спонтанністю, появою загального уявлення про роботу. Середній (емпіричний) рівень може бути досягнутий під час уведення педагогічних умов, за яких відбувається рефлексивний самоконтроль особистості над власними діями та вчинками; це рівень самоактуалізації. Високий (теоретичний) рівень здійснюється в разі впровадження умов для реалізації особистіснопрофесійних якостей керівника високої інноваційної культури.

Отже, розвиток інноваційної культури керівників закладів освіти визначається як фахова готовність до інноваційної діяльності та потенціал професіонала, а саме:

- усвідомлення фахівцем значущості його професійної діяльності для соціуму та для себе особисто;

- наявність певної суми знань, необхідних для успішної реалізації професійної діяльності;

- дотримання послідовності власних дій під час здійснення професійної діяльності;

- володіння певним набором психологічних якостей, необхідних у діяльності керівника 33СО.

Готовність до інноваційної діяльності, як багатокомпонентне та багаторівневе явище, має тенденцію до постійного розвитку та вдосконалення.

У контексті нашого дослідження цінною вбачаємо думку $E$. Листопадової щодо необхідності акцентування особливої уваги на розвитку інноваційної культури майбутнього керівника 33СО:

- на формування достатньої мотивації;

- на вдосконалення загальних і професійних знань у галузі управління;

- на вагомості постійного творчого саморозвитку;

- на провідних методах створення позитивного психологічного клімату в закладі освіти;

- на вивчення кращих європейських та вітчизняних практик функціонування 33 СО (Листопадова, 2015).

Розвиток професійно-педагогічної компетентності майбутнього керівника 33 зо забезпечить низка організаційно-педагогічних умов формування інноваційної культури, що має включати: 
- формування практично-ціннісного ставлення майбутнього керівника 33 дО до інноваційного управління як актуального аспекту професійної діяльності й засобу досягнення поставлених цілей;

- розуміння коригувальних дій в аспекті функціонального управління педагогічним процесом на основі активізації інноваційної діяльності закладу освіти;

-володіння методами створення в закладі освіти інноваційного середовища в контексті творчого пошуку та оптимізації професійної діяльності педагогів.

Таким чином, процес формування інноваційної культури керівника з3СО - це відкрита багатоетапна система, яка підкоряється певній логіці в розвитку.

На першому етапі має бути створений програмно-методичний комплекс для забезпечення інноваційного процесу.

Другий етап передбачає визначення ефективних моделей, технологій та методів підготовки керівників 33СО.

Третій етап - розробка навчально-пізнавальних завдань, покликаних допомогти керівникам закладів освіти визначитися з активною позицією щодо створення наукових повідомлень, творчих звітів, проектів, наукових публікацій, дисертацій, здійснення оцінки рівнів сформованості функцій культури керівника.

Серед пріоритетних напрямів програмно-методичного супроводу формування інноваційної культури керівника 33СО науковці виділяють:

- програмно-проектні (програми, проекти);

- організаційно-педагогічні (інтерактивні семінари, курси, майстеркласи, лізинг, консалтинг);

- інформаційні-освітні (створені сайти в Інтернеті, видавнича діяльність);

- експертно-аналітичні (діагностичні процедури, моніторинг, самоаналіз);

- маркетингові (вивчення запитів і формування груп на основі їх аналізу) (Листопадова, 2015).

Висновки та перспективи подальших наукових розвідок. Рівень управлінської компетентності керівника закладу освіти на інноваційних засадах забезпечує сталий розвиток освітньої установи, ії конкурентоспроможність на шляху європейської інтеграції. Входження України до Євросоюзу $\epsilon$ неможливим без розвитку інноваційного потенціалу нації. Сьогодення українського освітнього простору характеризується зміною змісту, форм, методів та засобів навчання, виховання й управління, зумовленою інноваційними процесами та реформуванням освіти. Теоретичні та методичні засади розвитку інноваційної культури майбутнього керівника 33 СО висвітлені в дослідженнях багатьох вітчизняних учених. Інноваційна культура як 
складова інноваційного потенціалу, що характеризує рівень освітньої, загальнокультурної та соціально-психологічної підготовки особистості та суспільства в цілому визначається Законом України «Про пріоритетні напрями інноваційної діяльності в Україні».

Сучасним менеджерам освіти доводиться вирішувати складні управлінські питання щодо забезпечення якості освіти, формування конкурентоспроможності закладу на ринку освітніх послуг. Якість управління в освіті відображається в успішності закладу й залежить від управлінської компетентності керівників освіти, від їх готовності до інноваційних змін. Інноваційна культура майбутнього керівника 33Со - це багатокомпонентне, багатоаспектне явище, покликане виконувати широкий спектр завдань.

Під час дослідження інноваційної культури управління в освіті слід спиратися на такі принципи: науковості, системності, гуманізму, професіоналізму. Інноваційна культура керівника $33 С 0$ пов'язана з його інноваційним і творчим мисленням, є основою його самореалізації і водночас сама зазнає трансформацій через вплив творчого мислення. Сучасні дослідники виділяють такі компоненти інноваційної культури керівника 33СО: когнітивний, мотиваційний, креативний, суб'єктно-діяльнісний.

Попри достатню розробленість окремих аспектів та завдань інноваційної діяльності керівника 33 Со подальших наукових розвідок потребує аспект розвитку їх інноваційної культури як детермінуючого фактору в підвищенні ефективності функціонування закладу освіти в сучасних умовах.

\section{ЛІТЕРАТУРА}

Закон України «Про пріоритетні напрями інноваційної діяльності в Україні» від 16 січня 2003 року N 433-IV (2003). Відомості Верховної Ради (ВВP), N 13, cm. 93 зі змінами, внесеними згідно із законом N 3076-IV (3076- 15) від 04.11.2005 (Law of Ukraine "On Priority Areas of Innovative Activity in Ukraine" of January 16, $2003 \mathrm{~N}$ 433-IV (2003). Verkhovna Rada (VVR) Information Bulletin, N 13, p. 93, as amended by Law N 3076-IV (3076-15) of 04.11.2005).

Клімова, Г. П. (2012). Інноваційний розвиток вищої освіти України: методологічний аспект аналізу. Актуальні питання інноваційного розвитку: Всеукр. наук.практ. конфр. 3, 90-105 (Klimova, Н. Р. (2012). Innovative development of higher education of Ukraine: methodological aspect of analysis. Topical issues of innovation development: All-Ukrainian scientific -practictical conf., 3, 90-105).

Листопадова, Е. В., Туркулец, С. Е., Аникеева Н. С. (2015). К вопросу о целесообразности системы менеджмента качества в вузе. Философия образования, 4 (61), 15-25 (Listopadova, E. V., Turkulets, S. E., Anikeieva, N. S. (2015). To the issue of the feasibility of a quality management system at the university. Education philosophy, 4 (61), 15-25).

Мармаза, О. І. (2016). Інноваційний менеджмент. Х.: ТОВ «Планета-принт» (M armaza, O. I. (2016). Innovation management. Kh.: Planet-print LLC).

Мурована, Н. М. (2012). Інноваційна культура керівника загальноосвітнього навчального закладу (теоретичний аспект). Народна освіта, 3 (18). Режим доступу: http://www.narodnaosvita.kiev.ua (Murovana, N. M. (2012). Innovative 
culture of the head of a comprehensive education institution (theoretical aspect). Public education, 3 (18). Retrieved from: http:// www.narodnaosvita.kiev.ua).

Мурована, Н. М. (2012). Інноваційна культура сучасного керівника закладу освіти: теоретичний аспект. Горизонти освіти, 2, 71-74 (Murovana, N. М. (2012). Innovative culture of the modern head of an education institution: theoretical aspect. Education horizons, 2, 71-74).

Нордстрем, К., Риддерстрале, Й. (2011). Бизнес в стиле фанк навсегда. Капитализм в удовольствие. СПб.: Стокгольм. школа экономики в Санкт- Петербурге (Nordstrom, K., Ridderstral, J. (2011). Funky business forever. Capitalism is a pleasure. St. Petersburg: Stockholm. School of Economics in St. Petersburg).

Погрібна, Н. С. (2007). Педагогічні засади інноваційного управління діяльністю керівника загальноосвітнього навчального закладу (автореф. дис. ... канд. пед. наук: 13.00.01) (Pohribna, N. S. (2007). Pedagogical principles of innovative management activity of the manager of a comprehensive education institution (PhD thesis abstract)).

Cac, Н. (2013). Сутність інноваційного управління як профресійної діяльності майбутнього керівника навчального закладу: зб. наук. пр. К. Ч. 1, 263-271 (Sas, N. (2013). The essence of innovation management as a professional activity of the future manager of education institution: coll. of scient. K. Part 1, 263-271).

Сас, Н. М. (2014). Підготовка майбутніх керівників навчальних закладів до інноваційного управління: стан та перспективи. Полтава: ПнПУ імені В.Г. Короленка (Sas, N. M. (2014). Preparing future managers of education institutions for innovation management: status and perspectives. Poltava: PNPU named after V. H. Korolenko).

Сидоренко, М. (2014). До проблеми готовності майбутніх керівників загальноосвітніх навчальних закладів до оцінювання якості освітньої діяльності. Гуманітарний вісник Державного вищого навчального закладу «Переяслав-Хмельницький державний педагогічний університет імені Григорія Сковороди». Серія: Педагогіка. Психологія. Філософрія: зб. наук. пр., Вип. 33, 147-155 (Sydorenko, M. (2014). To the problem of the readiness of future heads of secondary schools to evaluate the quality of educational activities. Humanitarian Bulletin of the State Higher Education Institution "Pereyaslav-Khmelnitsky State Pedagogical University named after Grigory Skovoroda". Series: Pedagogy. Psychology. Philosophy, 33, 147-155).

Kozlova, E. (2014). Структурные составляющие инновационной культуры будущего педагога (Structural components of teacher's innovative culture). Studia Pedagogicze. Problemy spoteczne, educacyjne i artystyczne, 24, 421-440.

\section{PEЗЮME}

Курок Вера. Теоретические и методические основы развития инновационной культуры будущего руководителя учреждения общего среднего образования в процессе магистерской подготовки.

В статье охарактеризованы основные теоретические и методические мероприятия развития инновационной культуры будущего руководителя учебного заведеня. Определяется содержание основных понятий, принципов и подходов к формированию культуры руководителя учебного заведения, обосновывается необходимость целенаправленной подготовки будущего руководителя учреждения к инновационной деятельности в управлении. Готовность педагога к инновационной деятельности определяется важным профессиональным качеством. Рассмотрена инновационная культура руководителя учебного заведения как составляющая его общей культуры. Отмечено, что инновационная культура руководителя учебного заведения, связанная с его инновационным и творческим мышлением, является основой его самореализации. 
Ключевые слова: инновационная культура, развитие инновационной культуры, руководитель учреждения общего среднего образования, магистратура, магистерская подготовка.

\section{SUMMARY}

Kurok Vira. Theoretical and methodological foundations of innovative culture development of the future manager of the general secondary education institution in the master's training process.

The article describes the basic theoretical and methodological measures of innovative culture development of the future manager of the general secondary education institution. The content of the basic concepts of principles and approaches to forming the culture of the manager is determined, the necessity of purposeful preparation of the future manager of the general secondary education institution for innovative activity of a manager is substantiated. The manager's willingness to innovate is determined by the important professional quality. The innovative culture of the manager of the general secondary education institution is considered as an integral part of his general culture, which is an integrative characteristic of a specialist and includes personal innovative potential formed during the implementation of social and educational innovations, style of management activity and manager's readiness to introduce new methods, content organization and management of the educational process. The manager's innovative culture ensures the readiness to generate and implement new ideas, the ability to support and implement innovative learning technologies in the educational process, the ability to implement modern management mechanisms in modern education.

The readiness of the manager of the general secondary education institution to introduce innovative activity is provision of quality educational service that meets the modern requirements for the future specialists' training. He is a professional in his field, who is creative in solving a particular problem or achieving a specific result. Of course, modernization of the education sector is not possible without innovative managers who are in line with the government's intended educational development strategy. While studying an innovative management culture in education, one should base him/herself on the following principles: scientific, systematic, humanism, professionalism.

It is stated that innovative culture of the manager of the general secondary education institution is connected with his/her innovative and creative thinking, is the basis of his/her self-realization and at the same time undergoes transformation due to the influence of creative thinking. Modern researchers distinguish the following components of the manager's innovative culture of the general secondary education institution: cognitive, motivational, creative, subject-activity.

Key words: innovative culture, development of innovative culture, manager of the general secondary education institution, master's degree, master's training.

удк 378: 811.14

Олеся Лазер-Паньків

Київський національний університет імені Тараса Шевченка ORCID ID 0000-0001-5281-5816

DOI 10.24139/2312-5993/2020.02/121-135

\section{ЧИННИКИ ПІДВИЩЕННЯ НАВЧАЛЬНОÏ МОТИВАЦІЇ У ПРОЦЕСІ ФОРМУВАННЯ ЛІНГВОСОЦІОКУЛЬТУРНОЇ КОМПЕТЕНТНОСТІ 3 ДАВНЬОГРЕЦЬКОЇ МОВИ}

Статтю присвячено аналізу чинників підвищення навчальної мотивації у процесі формування лінгвосоціокультурної компетентності з давньогрецької мови. 